\title{
A big picture: Connectedness between outdoor education, landscape and political reality in Australia
}

\author{
Robbo Bennetts
}

I want to look at the theme of connectedness in outdoor education. Connectedness is easy enough to conceptualise as a notion - in the way, for example, that chaos theorists famously connect the fluttering of a butterfly's wings in the Amazon rainforest with tsunamis in Japan. We can imagine water droplets connecting all parts of the globe by recycling themselves in perpetuity. We can imagine being connected to woolly mammoths or dinosaurs in the sense that chemical particles in our bodies may once have been the stuff of those creatures.

Tim Low passionately explored the organic connection between things during the "Dry \& ancient land" conference in Melbourne last June. He saw clear links between the ancient-ness of this continent and the variability of its generally meagre rainfall on the one hand, and the terrible environmental disasters that followed the arrival of early Europeans on the other. He showed how globalisation continues to pose threats to an environment that evolved largely in almost unparalleled isolation. These threats could wreak greater destruction than the rabbit.

Natural forces interact with humans not only to reshape nature, but also to re-shape human culture. Mainstream Australian culture has been re-shaped by this land in ways that make it distinct. As urbanised as we are, we Australians still tend to define ourselves in relation to the outdoors. We still inhale the dust from the dry interior. We are still touched by bushfires and droughts. We are still burnt by the summer sun. We may take refuge in cities but the land is embedded in our national psyche, and has left its imprint in everything we do.

How far, though, can this line of thinking be extended? Could the very flatness and aridity of this continent help explain the political cringe of successive national governments? Could it - dare I say? - help explain why Australia went to war against a distant and sovereign nation, with whom we had no quarrel, for the most spurious of reasons, against the wishes of both the overwhelming majority of Australians and people around the world?

If a team of social historians - say, one hundred years from now - sifted through whatever contemporary outdoor education publications and published works remained, I wonder what evidence they would find of the great political moments of our times? Such historical detectives would certainly find evidence of deep concern about the environment. They would find evidence of a sense that we need to educate the whole person, not only as an end in itself, but also as a means of creating a fairer and happier society. But I would be surprised if they found evidence of, for instance, the extent to which a war in the Middle East riveted the national consciousness, and triggered opposition measured, among other things, by opponents of the war taking to the streets in such unprecedentedly huge numbers.

I cannot think of any compelling reason why outdoor education publications ought report or mirror political reality. And I firmly believe that there must be very clear parameters relating to the ways in which teachers - and those in positions of authority generally attempt to exercise their influence over impressionable minds. (Rather than proselytise, I believe all educators should cultivate doubt, in the best traditions of liberal education.) The fact remains, however, that everything we do is informed by the bigger picture. And it is the bigger picture that connects everything.

To return to those earlier questions, how could something like the way in Iraq be connected to the dry and ancient nature of this land? Here is my guess. Largely because Australia's mountains have worn away, this continent is resource-poor in critically important resources like water and arable soil. We have not historically had the kind of resource base to support a large enough population or economy to independently defend ourselves from perceived threats from the North. Hence we have had a succession of governments since colonial times that have been willing to pay the price of sheltering behind a powerful ally. The price is a political (and cultural) cringe that most thinking Australians have long found distasteful, to say the least.

The obvious question that arises from the above is, what are the implications for outdoor educators? I believe that the kind of political awareness I have described establishes a context that, potentially at least, can make sense of everything we do. It can also help put things into perspective - if we keep the big things in frame, we are less likely to sweat the little things. There are many other implications as well. But ultimately, political awareness should help us to understand equally the importance of everyone working in the field of human-nature relationships coming together in a spirit of good will, and the uselessness of jealousy and fragmentation.

Let's be pro-active in our efforts to bring about a paradigm shift in the way we connect what we do with the great issues of the day.

\section{About the author}

Robbo Bennetts has specialized in teaching (mainly secondary) outdoor education for the past 15 years. He has recently self-published a middle school student workbook (Footprints) under the label of Wipeout Publications. He can be contacted at info@wipeout.com.au 